\title{
Reading Matters: Framing a Critical Conversation About Reading Across the Curriculum
}

A Review of Critical Reading in Higher Education: Academic Goals and Social Engagement by Karen Manarin, Miriam Carey, Melanie Rathburn, and Glen Ryland

Reading may be the single most common learning activity in higher education. While many faculty use lectures, discussions, exams, or writing assignments as part of their pedagogical practice, almost all of us assign readings. And nearly all of us complain about reading. Students don't read the assigned material, or they don't seem to have read it well, or they have difficulty thinking critically about or applying what they read. Yet despite its widespread use and well-known challenges, reading gets relatively little attention as a skill, except, perhaps, in literary and writing studies, which have developed complex theories about how readers construct meaning. In comparison, researchers have produced dozens of books and hundreds of articles on writing in the disciplines, as well as many on how to lead good discussions, the value of lecturing, and the factors that affect students' performance on exams. Critical Reading in Higher Education: Academic Goals and Social Engagement is thus an important contribution to our understanding of a key pedagogical tool.

But this is only one reason why this book is such a welcome addition to Indiana University Press's Scholarship of Teaching and Learning Series. Yes, the book offers important new insights into how students engage — or don't engage - with reading assignments. But it also offers important lessons for SoTL scholars about researching problems that traverse multiple disciplines, including the challenges and productivity of cross-disciplinary collaboration. Better yet, the study conducted by Karen Manarin, Miriam Carey, Melanie Rathburn, and Glen Ryland, all faculty at Mount Royal University in Calgary, makes a persuasive case for the value of critical analysis not only of students' failures but also, crucially, our own. Rather than merely identifying what did and did not work in their students' reading, these scholars considered how faculty actions contributed to students' difficulties. They also acknowledge the challenges involved in changing pedagogical practices to facilitate better critical reading.

Critical Reading in Higher Education reports on a collaborative, comparative study of students' reading in general education courses in four broadly-defined clusters addressing science and numeracy, cultural expressions and values, social structures and interactions, and communication. Designed as a "what is" study, the project began with a deceptively simple question: how do students demonstrate critical reading for academic goals and social engagement? The four authors all used a low-stakes responsive writing assignment, a reading log, in their courses. The assignment, which was required but not graded, asked students to answer three questions: "What is the reading about)?' 'So What (does it mean)?' and 'Now What (are you going to do with this information)'” (p. 23). After the courses were completed, the researchers worked together to analyze the reading logs using rubrics adapted from the American Association of Colleges and Universities' VALUE rubrics. The book summarizes their analysis, including similarities and differences across the courses. The authors also make a case for the larger significance of their findings.

CC-BY Licence 4.0 This is an Open Access article distributed under the terms of the Creative Commons Attribution License 4.0 International (https://creativecommons.org/licenses/by/4.0/), which permits unrestricted use, distribution, and reproduction in any medium, provided the original work is properly attributed. 
The "What?" of this project, to use the authors' terms, may not surprise many faculty: students can comprehend course readings, but they often struggle to read analytically and to view readings as relevant or productive beyond the specific needs of their courses. The authors' answers to the other two questions, however, suggest important and challenging insights. Three key points deserve particular attention. First, the project demonstrates clearly that faculty often contribute to students' problems with reading. When students decide not to do the reading, the authors suggest, this often reflects their understanding that they can easily get by without it. Even in courses in that included scaffolding and reflective assignments intended to foster critical and engaged reading, the researchers found, students could succeed without reading critically (p. 87). This is true for reading as part of the research process, as well. As the authors note, the traditional research paper assignment encourages students to locate and quote sources, not to read and reflect on the ideas that sources offer. Second, the study reveals an especially troubling gap in students' social engagement with course readings. If we want students to view reading assignments as sources of insight into their own lives and worlds, rather than simply as sources of content or texts for discussion, we must model and guide reflective, engaged reading. Finally, the study found that while students could be guided to read critically, their ability did not improve over the course of a term. The authors argue that if we value critical reading as a transferrable intellectual skill, we should embed attention to critical reading across the curriculum. Some readers may wish that the authors had devoted more attention to how to do this. Instead of offering prescriptions and strategies, the book emphasizes an analysis of the problem and a call to action.

This book demonstrates how SoTL can complicate our assumptions about students' behavior, especially when our research reveals that we have contributed to students' difficulties. Among the most powerful claims in this book is that faculty practices may inadvertently teach students not to read critically. In analyzing their data, the authors found patterns of student behavior, but they also dug deeper to consider how their own pedagogical practices might have influenced the way their students read and made use of texts. For example, after realizing that students rarely made connections among texts in their reading logs, the researchers speculate that "perhaps we would have observed more integration if we had specifically asked for it” (p. 54). In an especially ambitious and important move, Manarin read the articles her students had cited in their research papers, and she discovered that even the best of those papers reflected only surface-level reading. Students quoted from abstracts, cherrypicked statistics or one-liners, and misrepresented the arguments of their sources. But rather than blame students for what some might interpret as laziness, the authors recognize that students were doing what they thought they had been asked to do-find evidence to support their arguments — and that they had been rewarded for it. After all, they note of an especially strong student, "She didn't have to comprehend texts to get a good mark on the research paper assignment, so she didn't” (p. 62). What is impressive here is not only the insight Critical Reading offers into familiar pedagogical practices and challenges but the way the authors use the evidence to identify not only their students' struggles but their own errors. In treating failure as an opportunity for insight, the authors demonstrate an essential but difficult intellectual move for SoTL work.

Critical Reading in Higher Education ends with a powerful discussion of "Now What?" The authors argue that faculty in all disciplines need to think more explicitly and critically about the purpose and uses of readings in our courses. We must communicate more effectively what we value about reading, provide guidance for students in how to read well, and perhaps most important, ensure that reading well matters in our courses. They also encourage more discussion among faculty about how we define and foster critical reading. When the authors write that "we need to become advocates for critical reading across our institution," they include both themselves and their readers. While they acknowledge 
the challenges of creating change in higher education, they also insist that critical reading matters, in all disciplines, and that it deserves more discussion and more research. It also requires attention from a wider range of stakeholders_-students, administrators, parents, and beyond.

In developing their project, the authors have modeled the kind of critical cross-disciplinary conversations they advocate, and they provide a model for similar projects on other campuses. A collaborative and multidisciplinary study, Critical Reading in Higher Education translates the familiar idea of SoTL as an inclusive, diverse big tent field into a concrete and productive discussion of what we can learn from and with each other. The book clearly reflects the intellectual habits and contributions of both quantitative and qualitative researchers, weaving together theoretical concepts from literary and literacy studies with coding and data analysis methods. Even more important, the authors make their dialogic processes visible, from an opening chapter describing their context and the study, through their discussions of data from the various courses, and in a thoughtful, honest "Coda on Collaboration" that offers practical lessons but also inspiration for similar projects. SoTL projects often involve collaboration, but I know of few models as fully articulated or overtly comparative as this one. As valuable as this book is as a study of critical reading, it is perhaps even more valuable as a methodological case study for collaborative SoTL.

In Critical Reading in Higher Education, Manarin, Carey, Rathburn, and Ryland have produced a volume that addresses the frustrations many faculty feel about students' reading, provides rubrics and methods for studying critical reading, and models a collaborative, cross-disciplinary, and productively self-critical approach to SoTL. The authors also locate critical reading within a broader conversation about the purposes and values of higher education. As they point out, faculty cannot design strategies for teaching critical reading, much less develop the institutional will and vision to prioritize reading across the curriculum, without considering the purpose of reading within education as well as the purpose of education itself.

I'm tempted here to quote from the Jewish Passover seder: dayenu-all of this would have been enough. Yet the authors go one step further, although they are too modest to make this claim for themselves or for our field: they demonstrate the important role that SoTL can play in fostering and shaping such discussions. They close the book by calling for what Parker Palmer calls "transformational conversations." One can easily imagine campus groups interested in reading using this book as the basis for discussion, and both the findings and the scholarly approach would provide important guides. Critical Thinking in Higher Education may not only inspire others to join the conversation. It also provides insights and models to shape the discussion.

Sherry Lee Linkon is a Professor of English and Faculty Director of Writing Curriculum Initiatives at Georgetown University. She is the author of Literary Learning: Teaching in the English Major (Indiana, 2011).



Copyright for the content of articles published in Teaching \& Learning Inquiry resides with the authors, and copyright for the publication layout resides with the journal. These copyright holders have agreed that this article should be available on open access under a Creative Commons Attribution License 4.0 International (https://creativecommons.org/licenses/by/4.0). The only constraint on reproduction and distribution, and the only role for copyright in this domain, should be to give authors control over the integrity of their work and the right to be properly acknowledged and cited, and to cite Teaching \& Learning Inquiry as the original place of publication. Readers are free to share these materials - as long as appropriate credit is given, a link to the license is provided, and any changes are indicated. 